DOI: $10.19195 / 2084-5065.49 .6$

\title{
Handwriting examinations of historical documents
}

\author{
GINTARĖ HERASIMENKIENĖ \\ Forensic Science Centre of Lithuania, Vilnius, Lithuania
}

\section{Introduction}

Routinely, handwriting experts make examinations of recently-written or signed documents. Examination is based on the experts' knowledge on how people are writing now, and on his skills that help to recognize and evaluate handwriting features which are common or rare in a particular society. The older the document under examination, the more difficulties which can arise for a handwriting expert. Still, knowledge of forensic handwriting examination can be used to examine historical documents and can help to find important answers about historical events and personalities. This task requires the cooperation of historians or other scholars and a handwriting expert. In this article, I present some cases when state handwriting experts had made examinations of historical documents and share my observations on when such research is possible and what challenges experts are facing.

\section{The oldest document — the Trace of Basel}

The oldest document examined by handwriting experts in the Forensic Science Centre of Lithuania dates back to the 14th century. The entry is called the Trace of Basel, because it was found in an ancient book stored in the library of the University of Basel. A picture of a suffering man and 
a short entry in Old Prussian language are placed at the bottom of a commentary on Aristotle's Questiones super quattour libris metheororum written by Nicole Oresme (see Fig. 1). Transcription of the entry:

Kayle rekyfe thoneaw labonache thewelyfe

Eg koyte poyte nykoyte pēnega doyte

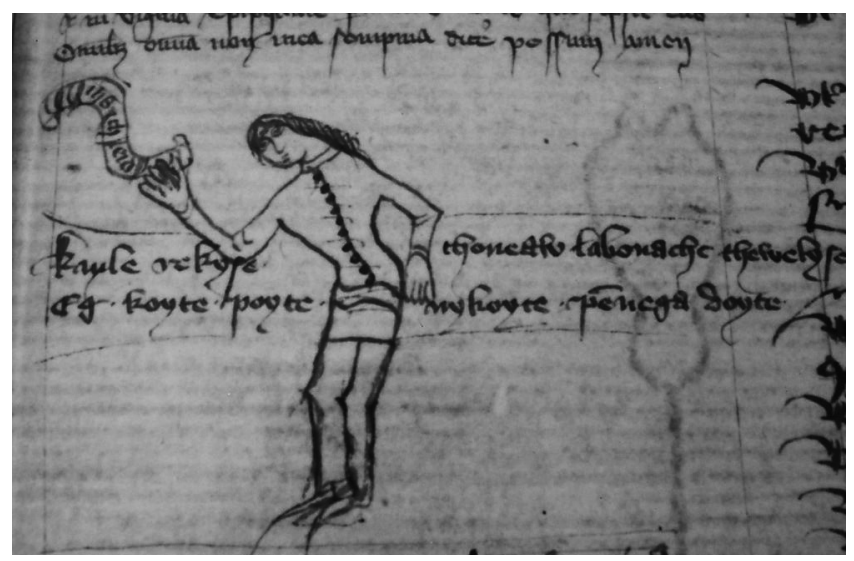

Figure 1. The Trace of Basel

Source: photograph by Gintarẻ Herasimenkienè.

An Ancient Baltic languages specialist from Vilnius University, Dr Diego Ardoino, asked for the handwriting examination of the historical entry, as the scholars are involved in the discussions as to who and why they had written the text. ${ }^{1}$ Scholars consider this entry as the oldest written text of Baltic languages. That is why they are interested to find out as much as possible about this text. However, the text posed more questions than answers. Even its meaning is not entirely clear. It can be translated as

To your health, sir! You are not a good fellow, If you want to drink and do not want to pay money. ${ }^{2}$

${ }^{1}$ D. Ardoino, "Interpreting and translating old Prussian micro-texts: the Trace of Basel", Vertimo studijos 2016, no. 9, pp. 7-20.

${ }^{2}$ S.C. McCluskey, W.R. Schmalstieg, V.J. Zeps, "The Basel Epigram: A new minor text in Old Prussian”, General Linguistics 1975, no. 15, pp. 159-165. 
The questions that were given to the handwriting experts were as follows: to ascertain whether the entry in the Prussian language was written by the same person or persons, and to establish who wrote other parts of the manuscripts in that and some other pages. For the examination, we received an enlarged copy of the documents of good quality, which made it possible to look closely at the details (see Fig. 2).

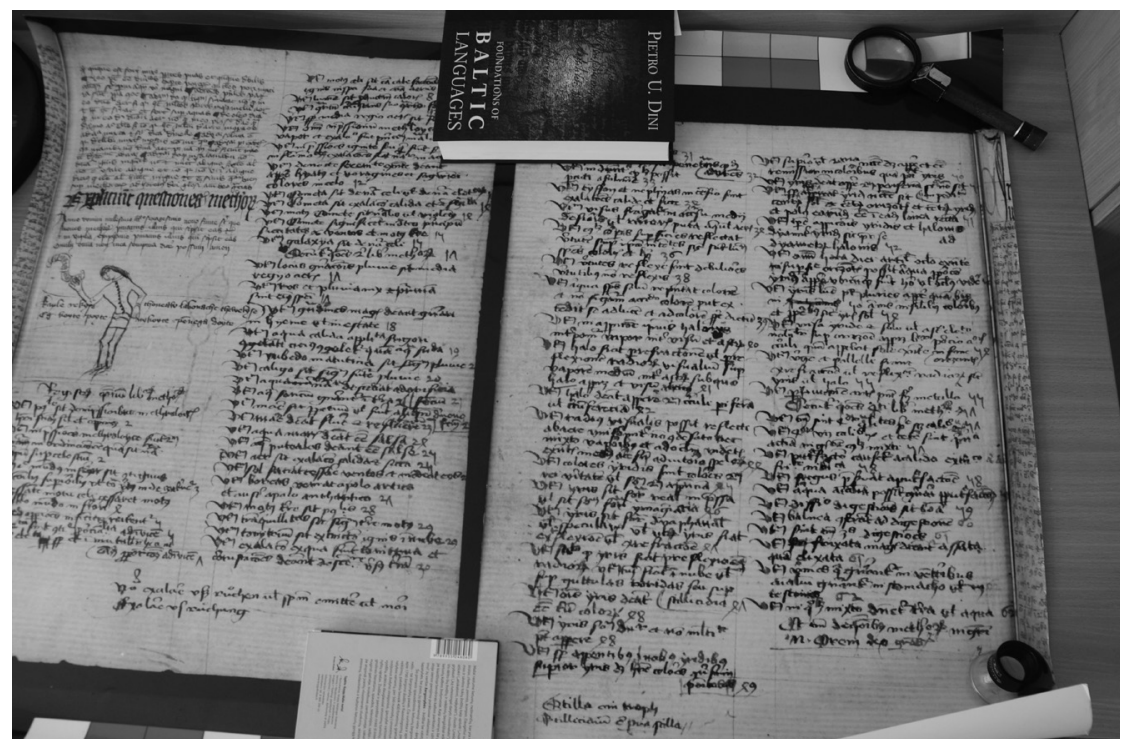

Figure 2. An enlarged copy of the page given for the examination

Source: photograph by Gintarè Herasimenkienè.

Examination of such kind of a document is a challenging task, and I will discuss the main difficulties the experts are faced with. The primary challenge for handwriting experts was old Gothic writing script, which differs significantly from how we are writing now. In addition, the texts were in old languages: the entry in Old Prussian and other entries in Latin and German. Therefore, examination was possible just having the texts transcribed - which allowed experts to identify the letters. The experts were faced with the problem of understanding abbreviations, because in the original text a lot of words were written using abbreviations presented in the form of a few letters. This is an uncommon style of writing for us. 
Nevertheless, in the transcribed text, they were written in full, with the purpose of showing the meaning of the text. This made it difficult to compare the transcribed and original texts and understand some words. Here are examples of abbreviations from the texts: domini $-\mathrm{dm}$, amen $-\mathrm{am}$, super — sup, magistri — mgri, Johannis — Johis, quod — q, animal — al.

Another challenge of such examinations is to become more familiar with the writing style of that time. When experts make examinations of texts written in their countries over the 10 last years, they use their experience and knowledge to evaluate which handwriting features are common and which are not so common in their society. But if they have the texts written in other countries, it can be challenging to evaluate handwriting features. This is a challenge when the text was written in the 14th century. It was essential to look at more texts written during the same period. Experts found another example of the writing in the 14th century and its transcription. It helped to be more certain of what types of letters were more common at that time. It was useful for the examination that the same letters were repeated in the Prussian entry, it allowed us to see how this person used to write them.

The examination was made by two experienced handwriting experts, Rasa Tamošiūnaitè (working as an expert for 20 years) and Anelè Žalkauskienè (working as an expert for 40 years). They concluded that the entry in Prussian was written not by the same persons as other parts of the texts. Also, it was not possible to reach a conclusion in relation to some shorter parts of the texts, because they were insufficiently comparable to the Prussian entry.

\section{Collection of proverbs from the 18th century}

Another old document analysed by Gintare Herasimenkienė and Anele Žalkauskienè, the handwriting experts from the Forensic Science Centre of Lithuania, was the collection of proverbs, adverbs and riddles entitled Litauische Sprichwörter und Rätsel written in the 18th century. It consists of Lithuanian proverbs, adverbs and riddles and their equivalent in German. Since the manuscript is not fully preserved, it does not have a title page, does not contain information about its author, and was considered anonymous. The scholars have raised hypotheses about its authorship, based on the content and linguistic features. Ancient writ- 
ings specialist Dr Ona Aleknavičienè, who had made a detailed study of the manuscript, decided that the author of the manuscript should be Jacob Brodowski (1697-1744) but some entries are written by another person. ${ }^{3}$ She turned to handwriting experts to test her hypothesis and finally justified it. Experts had to compare the manuscript of proverbs with samples of writing by Jacob Brodowski, who is an important figure for Lithuanian language history, because he had written a large Lithuanian-German and German-Lithuanian dictionary, entitled Lexicon Germanico-Lithvanicvm et Lithvanico-Germanicvm. The word usage was illustrated with examples of proverbs and sayings in this dictionary.

Good quality copies of the manuscript were submitted for examination. In addition, experts had visited the Vrublevskiai Library of the Lithuanian Academy of Sciences to see the original. One of the lists of the manuscript is presented in Figure 3 (you may notice that some entries in this page are written by another person with dark ink). The transcrip-

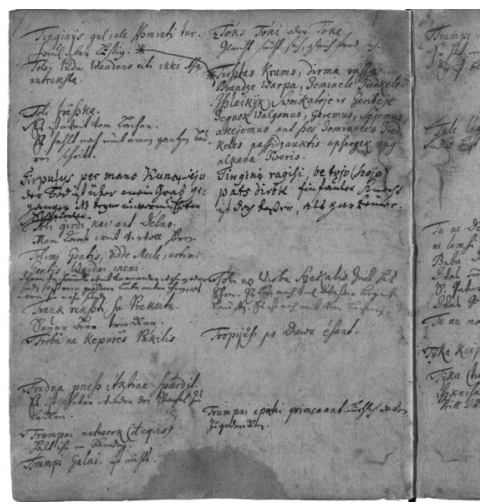

Figure 3. The page of the manuscript Litauische Sprichwörter und Rätsel

Source: O. Aleknavičienè, Jokūbo Brodovskio patarliu, priežodžiu ir mįsliu rinkinys Litauische Sprichwörter und Rätsel, Vilnius 2014, p. 326.

3 O. Aleknavičienè, "Rankraštinio šaltinio Litauische Sprichwörter und Rätsel atribucija", Archivum Lithuanicum 2011, no. 13, pp. 39-72. 
tion of the texts was also given to the experts. Figure 4 presents a fragment of the transcription of the page shown in Figure $3 .^{4}$ The texts of the Lithuanian and Latin abbreviations were written in Latin antiquity. The German entries were in the new Gothic script. So Lithuanian and German entries had to be studied separately.

$\backslash 24 \mathrm{v} I \backslash$

Tinginŷs gul, ale Ißminti tur.

Faul aber lültig ${ }^{1}{ }^{* 2}$

$\ulcorner$ Tolei Pi̊du Wandens eiti ikki Ala nutruklta. ${ }^{3}$

${ }^{\vee}$ Toli brâßka.

${ }^{\vee}$ Es ift weit vom Lachen.

Es fehlt noch umb eine[n] gantze[n] Bau= re[n] Ichritt. $\backslash 24 \mathrm{v}$ II $\backslash$

$\ulcorner 29$ Tóks Tóki oder Tóke

Gleicht fucht fich, gleich fand fich. ${ }^{110}$

$\left\ulcorner * 1^{11}\right.$ Tirßtas Krums, dirma ralla.

Brandze Warpa, 3eminele \{́́\}iedkele.

5 Ißlaikÿk Sweikatoje ir Geribeje

3egnok Walgomus, Geremus, Sejemus, akejemus ant ßos 3emineles 3ied= keles pallidzauktis aplergek nug alkana 3weris ${ }^{12}$. $^{13}$

Figure 4. The fragment of the transcription of the same page as given in Figure 3

Source: O. Aleknavičienė, Jokūbo Brodovskio patarlių, priežodžiu ir mịslių rinkinys Litauische Sprichwörter und Rätsel, Vilnius 2014, p. 327.

The experts used copies of Brodowski's dictionary as comparative material. Entries in the dictionary were both in Lithuanian and German and in the same writing style. Moreover, proverbs and sayings included in the dictionary, and the same Latin abbreviations were used. The experts have confirmed the scholar's hypothesis that Brodowski wrote the proverbial collection. The handwriting comparison example is shown in Figure 5 with the questioned entry on the top and Jacob Brodowski's samples below.

The experts also distinguished entries that were not written by Jacob Brodowski. Some 16 German and 11 Lithuanian phrases were added later to the manuscript by another author. These phrases are attributed to Gotfryd Ostermeier, who worked after Jacob Brodowski in the same parish. In Figure 6, you can see examples of Brodowski's and Ostermeier's entries from the manuscript with some handwriting features marked.

4 O. Aleknavičienè, Jokūbo Brodovskio patarlių, priežodžių ir mįslių rinkinys Litauische Sprichwörter und Rätsel, Vilnius 2014, p. 327. 


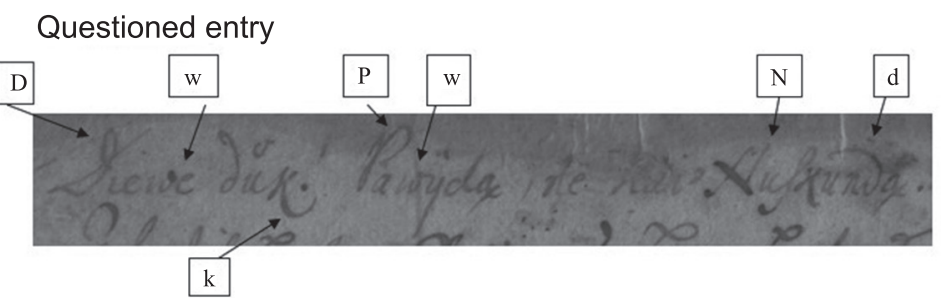

Diewe důk! Pawÿdą, ne kai' Nulkundą.

\section{Samples}

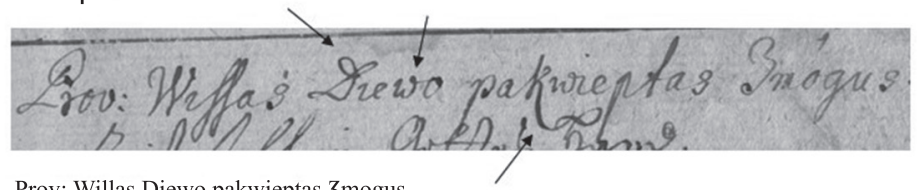

Prov: Willas Diewo pakwieptas 3mogus.

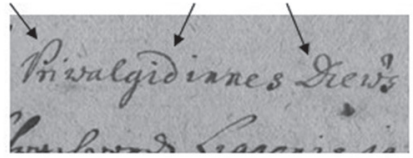

Priwalgidinnes Diew's

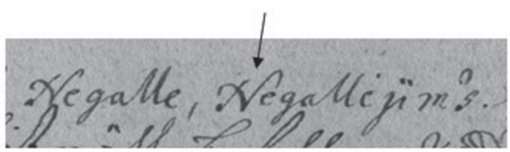

Negalle, Negallèjim's

Figure 5. Questioned entry and Jakob Brodowski's samples

Source: own work, based on the material submitted for the handwriting examination.

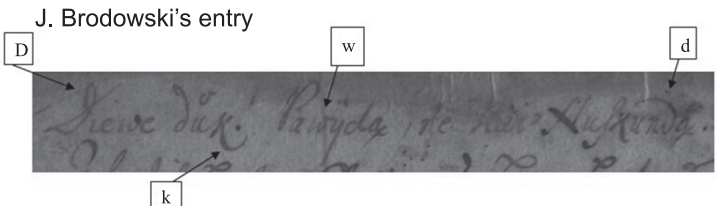

Diewe důk! Pawÿdą, ne kai' Nulkundą.

G. Ostermeier's entry

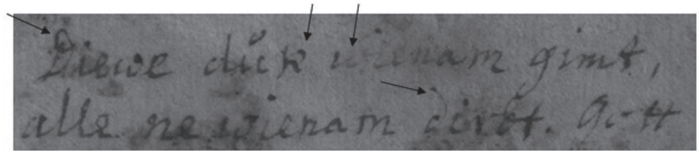

Figure 6. Jacob Brodowski's and Gotfryd Ostermeier's entries from the manuscript

Source: own work, based on the material submitted for the handwriting examination. 
From this examination we can conclude that the experts have faced the same challenges as with the Trace of Basel:

- The transcriptions of the texts were necessary for the examination to help the experts to separate the letters in the texts.

- Before making handwriting examination in old documents, it is important for the experts to gain more knowledge about writing styles at that time and to see writings of different people.

- Good quality copies of the documents should be submitted for examination.

\section{Constitution of the monastery from the 20th century}

The third examination that I discuss is an examination of the unfinished constitution of a monastery from the beginning of the 20th century. The Holy Family Sisters' Monastery in Vilnius functions until now. In their archive, they have an important document from the beginning of their monastery - the first unfinished constitution of the monastery. The document is printed by a typewriter and edited by hand. Corrections are recorded in black ink or pencil. Contemporary nuns wanted to learn more details about the establishment of the monastery and to find out if the document was edited by the founder of the monastery, Elžbieta Bendoravičiūtè. You can see the fragments of the document in Figure 7.

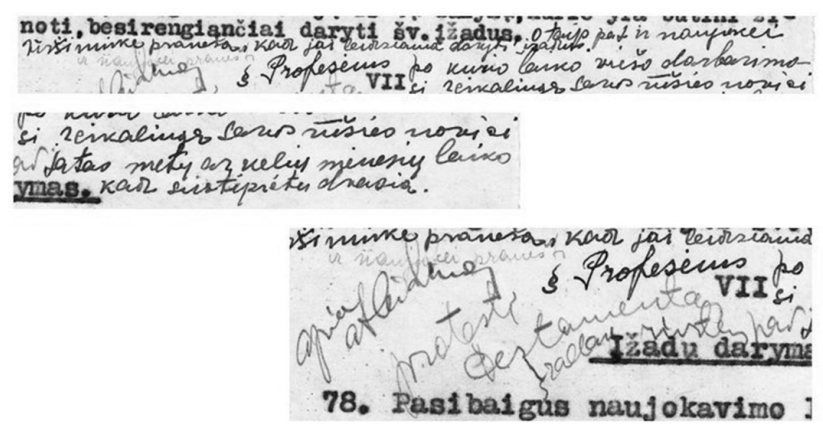

Figure 7. Fragments of the editing in the unfinished constitution of the monastery

Source: scanned from materials from the archive of the Holy Family Sisters' Monastery in Vilnius.

Nowa Kodyfikacja Prawa Karnego 49, 2018

(C) for this edition by CNS 
This examination was made by Gintare Herasimenkienè and Anelè Žalkauskiene, the handwriting experts from the Forensic Science Centre of Lithuania. In this case, the handwriting is more similar to how we write nowadays. Still, it is important for the expert to see more examples of writing from that period. The main difficulty in this examination was the lack of handwriting samples. After asking for more samples, experts had just four documents with the handwriting of Elžbieta Bendoravičiūtė and it was still not enough - some letters were missing in the samples. Few handwriting samples of a person preserved is a common problem in the investigation of old documents. Experts have managed to make the conclusion that five entries in the Constitution text were written by Elžbieta Bendoravičiūte. But other entries were left inconclusive for the following reasons:

- A lot of entries were filled in the narrow spaces between lines of printed text. In such a situation, letters became smaller, simpler, their shape changes, some differences occur with regular writing.

- Entries were not written at the same time, and some of them were very short, so there was not enough graphical information for a conclusion.

- The last reason was the lack of samples. The experts couldn't find in the samples some letters, and the samples could not represent all handwriting variations of Elžbieta Bendoravičiūtè.

\section{Lack of samples - one of the main difficulties}

It is interesting to notice that the lack of samples also was the main difficulty while making an examination of a crucial document for Lithuanian history - the Act of Reinstating Lithuanian Independence, which was signed by the Council of Lithuania on 16 February 1918. Last year, the original document was found in the Diplomatic archive in Berlin and was brought to Lithuania. It was surprising how quickly the historians began to make hypotheses of who wrote the text of the document and even assert that it is the signatory of one or another person. But historian Liudas Mažylis applied to approve his version to the handwriting experts. The Lithuanian Police Forensic Science Centre examined it. 
Even though the handwriting of the independence Act is clear, the study was not easy for reasons similar to the previous case, that is, the lack of handwriting samples. Despite the fact that Jurgis Šaulys, the person who wrote the Act, was an active public figure and politician as SecretaryGeneral of the ensuing Council of Lithuania, it was not easy to find his handwriting samples. At first, just one sample was given, and it was a letter written in 1935, 17 years after the Act. Experts asked for samples which would be closer in time. After searching in archives and libraries, some other samples were found, among them a letter from $1917 .{ }^{5}$ It helped to make the conclusion.

\section{Conclusions}

This overview of the examinations of historical documents demonstrates that handwriting experts can help scholars to determine who had written a document or its entries even when a document is old. However, such examination requires a lot of work. In particular, scholars should elaborate their hypothesis, transcribe texts and find suitable handwriting samples. In addition, a handwriting expert must gain knowledge of the style of writing in that period. This requires more efforts from both scholars and experts. Handwriting experts enrich and deepen their knowledge in doing such examinations and this expands the possibilities of using forensic knowledge simultaneously.

\section{References}

Aleknavičienė O., Jokūbo Brodovskio patarliu, priežodžiu ir mįsliu rinkinys Litauische Sprichwörter und Rätsel, Vilnius 2014.

Aleknavičienė O., "Rankraštinio šaltinio Litauische Sprichwörter und Rätsel atribucija", Archivum Lithuanicum 2011, no. 13, pp. 39-72.

Ardoino D., "Interpreting and translating old Prussian micro-texts: the Trace of Basel", Vertimo studijos 2016, no. 9, pp. 7-20.

5 Lietuvos policijos kriminalistiniu tyrimu centro ekspertai teike išvadas dèl $1918 \mathrm{~m}$. Lietuvos Nepriklausomybés Akto, http://ktc.policija.lrv.lt/lt/naujienos/lietuvos-policijos-kriminalistiniu-tyrimu-centro-ekspertai-teike-isvadas-del-1918-m-lietuvos-nepriklausomybes-akto (accessed: 22.09.2018).

Nowa Kodyfikacja Prawa Karnego 49, 2018

(C) for this edition by CNS 
Lietuvos policijos kriminalistiniu tyrimu centro ekspertai teike išvadas dèl 1918 m. Lietuvos Nepriklausomybès Akto, http://ktc.policija.lrv.lt/lt/naujienos/lietuvos-policijos-kriminalistiniu-tyrimu-centro-ekspertai-teike-isvadas-del-1918-m-lietuvos-nepriklausomybes-akto (accessed: 22.09.2018).

McCluskey S.C., Schmalstieg W.R., Zeps V.J., "The Basel Epigram: A new minor text in Old Prussian”, General Linguistics 1975, no. 15, pp. 159-165.

\section{Summary}

In this article, some cases of historical document examinations by handwriting experts are presented: examination of an entry in Old Prussian from the 14th century, examination of a collection of proverbs from the 18th century, written in Lithuanian and German and the examination of the constitution of a monastery from the beginning of the 20th century. The author of the article shares her observations on when such examinations are possible, what challenges experts are facing and provides recommendations for the conduct of examination of historical documents.

Keywords: handwriting examinations, historical documents, handwriting samples, Gothic script, Latin antiquity script. 